\title{
7 NAMES AND NAMING: SPEAKING FORMS INTO PLACE
}

\author{
Franca Tamisari
}

In 1946 Donald Thomson (1946:157) noted that 'very little has been recorded of the derivation and use of personal names among the Australian Aborigines'. Despite the significance that Australian Indigenous people in general give to the meaning and use of proper names of people and places and to the action of naming in cosmogonic events, with some exceptions this neglect continues today. ${ }^{1}$ Thomson explains this dearth of research by the secrecy and the sacredness of proper names and toponyms which derive from their ancestral associations and by the rules of avoiding names in everyday life. However, like Keith Basso (1988:103), I am inclined to suggest that this neglect is the reflection of the prevailing preoccupation of anthropologists and linguists with the semantico-referential meanings and functions of names and language rather than with the culturally shared notions and images all names evoke, provoke and embody in the creative dialogue that people establish and continuously renew with country. As Heidegger argues for language (1971a:192-193): in order to explore the meaning and significance of Yolngu ${ }^{2}$ names it is necessary to explain them more comprehensively than considering them as simple expressions of internal feelings and thoughts, as mere representations of reality, as vehicles by which people communicate, address each other, or in Levistraussian terms, as a means by which people classify the world and order themselves within it (see Lévi-Strauss 1966:161-190). If with Heidegger I suggest that 'language speaks' beyond expression and representation, my concern in this paper is to ethnographically explore what Yolngu names speak of, that is, what culturally shared images and notions they reveal while saying very little (Basso 1988:103). As in other regions of Indigenous Australia, Yolngu names - whether they be of individuals,

The following authors have given some attention to the significance of names: Hart (1930); Goodale (1980); Dussart (1988); Schebeck (1968); Stanner (1937); von Sturmer (1978); Williams (1986); and more recently Biddle (2000) and McKnight (1999).

2 North-east Arnhem Land extends approximately from Cape Stewart in the west to the Gulf of Carpentaria in the east and from the Wessel Islands in the north as far south as the Koolatong River north of Blue Mud Bay and includes the major settlements of Maningrida, Milingimbi, Ramingining, Gapuwiyak, Galuwin'ku and Yirrkala (see map). Yolngu (human being) is the term used by north-east Arnhem Landers to refer to themselves in relation to their western neighbours of central Arnhem Land. By extension the term Yolngu is used to mean 'Aboriginal or Black people' in contrast to Balanda, 'non-Aboriginal, White people'.

L. Hercus, F. Hodges and J. Simpson, eds, The Land is a Map: placenames of Indigenous origin in Australia, 87-102.

Canberra: Pandanus Books in association with Pacific Linguistics, 2002.

C Franca Tamisari 
groups, plants, animals, sacred or non-sacred objects such as cars, boats and dogs - are associated with the group's specific cosmogonic actions and the movements of Ancestral Beings who gave shape to the land, brought everything into existence at particular places, and bestowed countries and all phenomena upon specific groups of people. The general point I would like to make is that not only toponyms but all proper names are ideolocal (Casey 1996:26), that is, specific to place, as they derive from and refer to the unique cosmogonic events and actions performed by Ancestral Beings at particular places (cf. Morphy 1995:192). ${ }^{3}$ The specificity of names is so precise that in many instances for knowledgeable men and women the proffering of a name discloses the named person's affiliation with and his/her potential rights and authority over specific places.

While the link between places, events and names has been repeatedly noted in relation to Australian Indigenous cosmologies (Stanner 1979a, 1979b; Munn 1970) and ancestral bestowal of and rights over country (Williams 1986), the interlocking of these elements, the shaping of places through ancestral events and the ways places and events are condensed in names need further detailed attention. If language speaks by itself of our being-in-the-world as Heidegger argues, I suggest that Yolngu names speak of places as events or happenings (cf. Casey 1996:27) and with places, of belonging, of self-identification with and ownership of landscape features, of rights and authority over country.

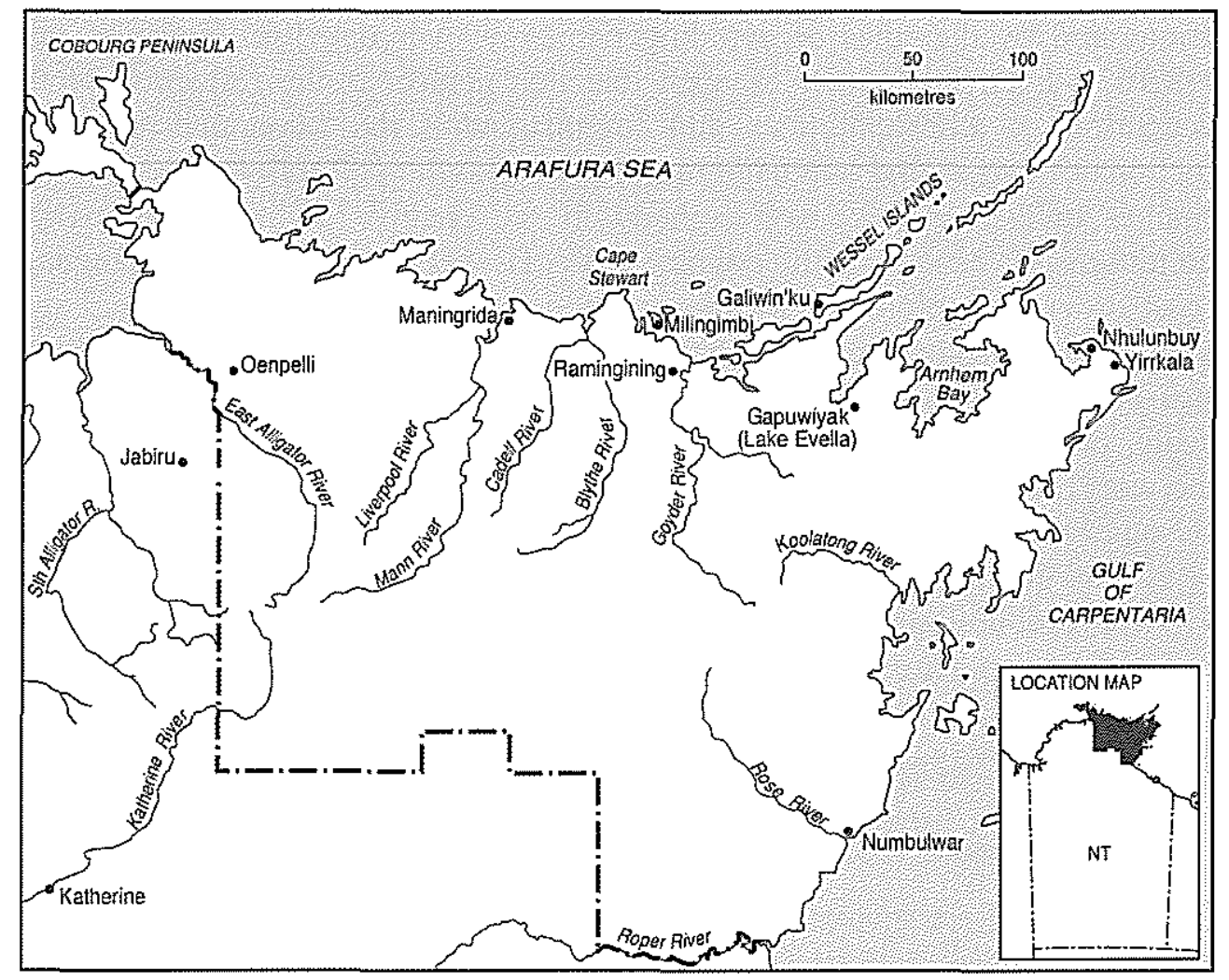

Map 1: North-east Arnhem Land

3 Casey (1996:26) refers to places as ideolocal as a 'place is more an event than a thing to be assimilated to known categories. As an event, it is unique, ideolocal'. 


\section{1 'WHERE IS YOUR NAME FROM?'}

The connection names establish between people and country is well illustrated by the expression 'to have a name' (ya:ku-mirr, literally name-having) which, in fact, underlies the link between people and their group's Ancestral Beings, stresses an association with a particular place and implies notion of belonging and owning country (cf. Williams 1986:42). ${ }^{4}$

Every Yolngu person is said 'to follow the father' (ba:paw malthun) and is born and is a member of his or her father's group. Identification with one's patrilineal country (ngaraka literally 'bone country') is principally expressed through 'bone names' (likan and bundurr, literally 'elbow' and 'knee') which are inherited, learnt and given during the many stages of one's gradual acquisition of knowledge from one's patrilineal relatives (both biological and classificatory). I refer to 'elbow' and 'knee names' inclusively as 'bone names' rather than 'power names' as is common in the literature, in order to maintain some of the Yolngu associations and imagery. As Yolngu talk about one's patrilineal land as 'bone country' - the country one's ancestral substance comes from before birth and returns to after death - elbow and knee names may be seen as at once conveying the sharing of bony substance with patrilineal country as well as, perhaps, comparing the main joints which give movement to the body to the dynamic articulation of people, Ancestral Beings and places (cf. Keen 1995:509512). Before being conceived, a child announces his/her imminent conception to the father-to-be by appearing to him in the form, 'shadow' or 'image' (mali' or wunguli') of an animal, phenomenon or plant which is believed to be the embodiment of an Ancestral Being (wangarr). This embodiment belongs to the father's group or to one of the father's patrilineally related groups. Such conception signs consist of unusual events happening at a place in the country of the father or of a patrilineally related group. One of the names given to the child often refers to such a place (dhawal) where the child first manifested him/herself. Just as the Yolngu term for 'to be born' translates as 'to think of (such) a place' (dhawal-guyanga, literally 'place of origin-think') and thus 'associates the individual with ancestral creativity' (Morphy 1995:197; see also Williams 1986:88) at a particular named place through the conception sign, so the same term is used for 'to die'. The expression 'his place of origin was silenced' (dhawal mukthurra nhangu, literally 'his place [was] silenced'), not only links the death of a person with a place of conception or origin but also stresses the 'interanimation' (Basso 1996:55) of place, ancestral being and person. One of the purposes of the mortuary ceremony is to send the ancestral component of a person back to his/her bone country: after a person's death until the concluding 'cleansing' ceremony (bukulup, literally 'face washing'), the bone country and/or the place of origin (dhawal) of the deceased becomes barren and his house, possessions as well as the places where he would spend most of his/her time while living, cannot be entered, frequented or used. ${ }^{s}$

In addition to bone names one also has several personal names $(y a: k u)$, which are given at birth by several patrilineal and matrilineal relatives such as one's FF (ma:ri-mu), F (ba:pa),

4 The term wakingu is used to indicate that a person does not belong to anyone and anywhere, thus a person without relatives who care and look after him/her. The expression ya:kumiriw, literally "name-having-PRIV" is used to address and to refer to a person whose name cannot be pronounced because it is the same or it sounds like the name of a recently deceased person which cannot be proffered for a period of time from one to two years after his/her death (cf. Nash and Simpson 1981).

5 Dhawal conveys several meanings at once. It refers to 'breath' and 'feeling' as well as to 'the place at which a child to be born manifest itself' through the conception sign. 
FZ (mukul ba:pa), MM and MMB (ma:ri). ${ }^{6}$ Given that several relatives may give a newborn more than one name each, a person may have from four to fifteen proper names which thus associate him or her with particular places over which the name-givers have strong or potential rights.

Generally speaking, not only toponyms but all proper names can be said to be ideolocal, that is, specific to particular places, as they derive from and refer to the unique cosmogonic events and actions performed by Ancestral Beings at particular places where they shaped the land through bodily processes. That all proper names of groups and individuals refer to specific events at particular places is well illustrated by the fact that they are said to be derived FROM (puy) a place (wa:ngapuy ya:ku, literally, 'place-FROM names') or as being IN (ngur) a place (wa:ngangur ya:ku literally 'place-IN names'). Thus, when inquiring about a person's name one asks 'what is your name from?' (nhapuy nhe ya:ku) or 'what is your name in or at?' (nhangur nhe ya:ku). ${ }^{7}$ To these questions people answer by saying that their names are FROM natural phenomena such as the wind, clouds, and rain (watapuy, wukunpuy, waltjanpuy) or IN Ancestral Beings such as birds, trees, waters and spears (warrakanngur, dharpangur, gapungur, and garangur). While the first answer to this question can just stop at indicating the generic name of a phenomenon or a placename on a particular country such as 'from the cloud' or 'from the sea water', the clouds and the seagull are known with the group's specific names and are associated to particular ancestral bodily actions, an integral part of the ancestral events which gave shape to the country as it is today.

The following examples illustrate how names refer to specific places where particular ancestral events and often particular bodily actions took place at specific times of the year and locations. ${ }^{8}$

'name from (a) bird' (warrakangpuy ya:ku):

1) The female proper name $\left({ }^{*}\right)$ 'beak of a species of seagull' refers to the feeding of the young seagulls just after the breeding season on the shores at a particular beach belonging to the Djambarrpuyngu clan of the Dhuwa moiety.

'name from (the) clouds' (wukunpuy ya:ku):

2) The male proper name (*) 'long black clouds, heavy with rain on the horizon' announces the beginning of the monsoon season as observed from another shore of the Djambarrpuyngu clan.

'names from (the) rain' (waltjanpuy ya:ku):

${ }^{6} \quad$ Father's father (FF); father (F); father's sister (FZ); mother's mother (MM); mother's mother's brother (MMB).

7 What is your name? is rendered with: 'yol nhe ya:ku?' literally 'who you name?'

8 Please note that names are glossed with their ancestral references and not translated literally. Given the general secret/sacred nature of the different types of Yolngu names, the association they evoke, the power they summon, the authority they confer and the emotive response they might arouse when they are pronounced, throughout this paper I will omit them by inserting an asterisk $\left(^{*}\right)$ and by glossing them in English. 
3) The female name $\left(^{*}\right)$ 'small rain' refers to the drizzle that follows the foggy mornings at the end of the monsoon in Wangurri country of the Yirritja moiety.

4) The male name (*) 'rain which makes one cold' brings the cold season from the east and makes everything grow on Djambarrpuyngu country.

name derived from ancestral imprinting action on the land:

5) The female name (*) 'from the head' refers to the hill shaped by Shark ancestor hitting the ground at a particular place on Djambarrpuyngu country.

name derived from ancestral externalising action (see below):

6) The male name of $\left({ }^{*}\right)$ 'low, small white triangle-shaped clouds' refers to the clouds that were spurted by the Serpent over the inlet where he rests in the deep waters of the Gupapuyngu-Birrkili group of the Yirritja moiety.

name derived from a conception sign:

7) The female name (*) 'water corm' refers to the unusually large corms through which the 'shadow' of a baby girl first appeared and thus was 'found' by her father to be at a place patrilineally related to the Wangurri group of the Yirritja moiety.

Despite the fact that 'bone' and personal names and their ancestral associations with particular places and events seem to be known by most people of mature age, they are seldom used and in certain contexts avoided altogether. In addition to the strictly observed avoidance of pronouncing the proper names of certain relatives, such as the names of a man's sister (midiku') and of a woman's son-in-law (gurrung), proper names of recently deceased people cannot be pronounced aloud in the same way that their photographs cannot be shown in most parts of Indigenous Australia. If in the first instance the speaking of a name is said to cause swelling of the speaker's lips, in the second the recently deceased person is said to be summoned among the living as a duplicate of his/her body (mokuy, cf. Warner 1958:446) or 'flesh soul' as I prefer to refer to it. Pronouncing the name of a recently deceased person thus disrupts the process whereby the idiosyncratic component of an individual (mokuy) needs to be dispersed in order to send his/her ancestral component or 'bone soul' (birrimbirr) to merge with his or her land of origin or 'bone-country'. ${ }^{10}$ Whereas bone names are mainly proffered in the songs and chanted in long lists during ceremonial climaxes, personal names are seldom used as terms of address in everyday life. For everyday social interaction kinship terms,

$9 \quad$ As Ancestral Beings and associated phenomena are group-specific, their names are considered the possession of the clan. Despite the fact that most Ancestral Beings cross the countries of several groups, during their travels they change language so that the proper names derived from their actions are different.

10 Onomatopoeic words or as Yolngu say words that are 'close' (galki) in sound to the deceased names are also dropped from the current spoken vocabulary and substituted by alternative nouns. In the light of this it is interesting to note that the sound itself may evoke ancestral association and certainly has the power of summoning the 'flesh soul' of the individual which appears like the deceased in all aspects but it is endowed with supernatural and often malevolent powers. On a few occasions, and mainly for my own benefit, the name of the deceased was whispered to me. Similarly photographs were occasionally shown to me underneath a sheet, inside a skirt pocket or sheltered by the hand. A discussion that explores the way in which sounds, like images, can summon someone to presence cannot be pursued here. 
subsection or so-called skin-names (ma:lk) and nicknames (wakal ya:ku) are preferred and widely used."

While the 'kind of oneness' as Stanner (1979a:35) remarks, which includes 'notions of the body, spirit, ghost, shadow, name, spirit-site and totem', has been repeatedly noted in the Australian Indigenous lifeworld, the interanimation of these elements, the shaping of places through ancestral events and the act of naming needs to be explored in some detail. If language speaks by itself of our being-in-the-world, as Heidegger argues, I suggest that Yolngu names speak of places, and more precisely they speak of the 'corporeal connection' (Stanner 1979b:135) between ancestral bodies and country and of the sociophysical relationship of people with place which is at the basis of people's self-identification, ownership of and rights over land.

In what follows I will limit myself to explore the corporeal connection between ancestral bodies and country, how names and the act of naming are fused with processes of bodily transformation and, conversely, how these bodily transformations involve names and the act of naming. In order to explore the interpenetration of ancestral bodies, places and names, how places are shaped by names and how names embody places, it is necessary to consider Yolngu cosmogonic events, to which I now turn.

\section{NAMING PLACES AND PLACING NAMES}

As elsewhere in Indigenous Australia (cf. Strehlow 1947), in Yolngu cosmology, land has always existed but it was originally empty, shapeless and nameless. The landscape people inhabit was shaped into its present form by Ancestral Beings (wangarr) who roamed through the sky, above and below the surface of the earth, in the depths and shallows of the sea and along the rivers, thus shaping everything into existence in the geographic and climatic environment through cosmogonic movements and actions. The landscape was fashioned and oriented, transformed and moulded by the ancestral bodies through several bodily processes. These have been described as: metamorphosis, imprinting, externalisation (Munn 1970), placement and orientation. ${ }^{2}$ Similar to the way that Munn (1970:142; 1973:132) noted the association between name, song and visible mark, which are implied in the term yirdi and yini in Warlpiri and Pitjantjatjara languages respectively, the processes of transformation, and especially imprinting, metamorphosis and externalisation, are intrinsically connected with names and the action of naming. In talking of these transformation processes and dynamics which link naming and action, language and movement, I will employ the term morphogenesis in order to avoid the misleading term of creation. As Williams points out (1986:28) quoting Stanner, in Yolngu cosmology there is no creation ex-nihilo but rather processes of generating, shaping forms into presence. At certain stages of their journeys

II It must however be noted that personal names are often used as terms of address among members of a family who reside together (cf. Stanner 1937:302). As terms of address, in this context, personal names are often shortened thus further reflecting the intimacy of these relationships. People have also 'White names' (balanda $y a: k u$ ) which, together with one Yolngu personal name, are mainly but not only used for bureaucratic purposes and in interacting with balanda (White) people (see Biddle 2000).

12 To the cosmogonic processes identified by Munn (1970), Keen adds 'placement' (1978:45) or 'turning' (Keen 1994:44-45) by which the ancestors or objects used by them are transformed into a landscape feature. To this list I added 'orientation' as landscapes are not only perceived as transformations of ancestral actions but as being ordered and positioned along the path by the direction and movement of ancestral bodies (Tamisari 1998:254). 
Ancestral Beings metamorphosed, imprinted and externalised whole or part of their bodies into topographic features such as a stone, a hill, the trees along a river, clouds, lightning, animals and plants. Ochre quarries are said to be ancestral faeces, a yellow clay which turns red after cooking is their blood, and clouds were formed by the water which spurted from their mouths (name no. 6; see discussion below). During their wanderings over the land, sea and sky, Ancestral Beings and the objects used by them in a certain manner, left a mark behind. Where a tree was felled to collect wild honey a long depression is to be seen today, where an ancestral bee struck its proboscis a round hole is perfectly cut into the surface of a flat rock. In Yolngu languages, these processes of shaping or imprinting are referred to as 'hitting the country' (wa:nga buma). Whenever an Ancestral Being hit the ground with a part of its body a mark remained to manifest its passage and action and to embody its power. Landscape features thus shaped are not only transformations of ancestral body parts but also the embodiment of particular actions which identify unique cosmogonic events (cf. Munn 1996:457). It is the uniqueness of these 'action features' that is condensed in the toponyms and other proper names given by the ancestors in the act of shaping the land and bestowing tracts of country upon people. ${ }^{13}$ Thus names may be seen as localising events, manifesting actions and congealing movement. Here I use the word 'manifest' in its primary sense of 'palpable' which interestingly derives from the etymology of 'manus' (hand) and 'festus' (struck) as in 'of-fend' and 'de-fend'. In this sense the term manifestation is apposite in describing Yolngu cosmogony as revealing the world through form by striking the land with parts of the ancestors' bodies (see name no. 5).

I will now turn my attention to explore how this shaping of the ground involves the act of naming and, conversely, how names thus embody ancestral morphogenetic processes. I suggest that names do not only refer directly or indirectly to specific places stressing their bestowal upon particular groups, but, once again, they reveal the corporeal connection between people, places and ancestors. As I discussed elsewhere, like designs, songs and dances, names are manifestations, and as such they are visible marks or, as Yolngu would say, the footprints of the Ancestral Beings (cf. Tamisari 1998).

Each moiety has what may be referred to as a creation myth which is said to precede all other ancestral events. The Djang'kawu Sisters along the coast and the Wagilak Sisters inland are the first Ancestral Beings of the Dhuwa moiety. The Lany'tjung and Barama brothers are responsible for bringing into form Yirritja moiety countries, phenomena and people. Despite the fact that these 'first' myths may be distinguished from more clan-specific mythological stories of ancestral journeying (cf. Morphy 1990:313), they all share similar processes of morphogenesis which are characterised by the combination of naming, movement and action upon the land. Although the myth of the Djang'kawu Sisters belongs to the Liyagalawumirr clan of the Dhuwa moiety and concerns the shaping of the Dhuwa clans' landscapes, it is referred to and considered by all Yolngu people of both moieties as the first and most significant cosmogonic story. It was pointed out to me, more than once, that the Djang'kawu Sisters gave forms and named everything, both Dhuwa and Yirritja. To prove this claim some people went on to say that the Sisters' language, now sung in the associated songs, is a mixture of Dhuwa and Yirritja languages. ${ }^{14}$

$\overline{13}$ Djon Mundine (2000:100) uses this phrase to refer to the visual embodiment of ancestral events in Yolngu bark painting.

14 On being questioned on this matter, a Yirritja man answered by recognising the role of Latjung and Barrama as the first Yirritja Ancestral Beings but also confirmed the above claims with the following somewhat puzzling statement: 'The Yirritja ancestors took the names from the two Sisters wherever they went. They 
In the following brief introduction to the Djang'kawu song cycles given by Charles Manydjarri, one of the eldest owners of the Djang'kawu ritual complex, he focused on the Sisters' power of morphogenesis through naming. In his words:

The first songs talk about where the two Sisters came from and where they are directed to. They describe how rich they are in sacred objects (madayin) and how they strode by using their yam sticks like walking sticks (ngal'gam). The first bird they saw was a blacktailed cockatoo sitting on a special tree that they called $(*) .^{15}$ They gave that tree a

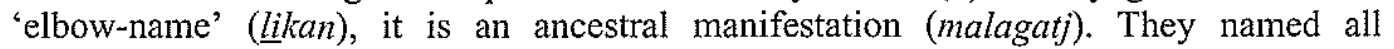
creatures, birds and places. Where they planted (nhirrpan) their sticks springs of fresh water (milminydjarrk) sprung out of the ground and a sacred tree stood (dha:rra). They created everything. They created children and clans, they gave names to the land and gave the land to the people. (Charles Manydjarri: extract of conversation recorded by the author in Milingimbi, field tapes 1991)

Emphasis is given to walking and planting the yam stick in the ground; and these actions form the focus of the song text and the rhythm as well as of the movements of the public dance of the Djang'kawu Sisters. ${ }^{16}$ Wherever they planted their walking or yam stick, a tree grew and/or a freshwater spring burst through the ground. Wherever these activities took place, the Sisters gave elbow names (likan) to the land and other phenomena which were then bestowed upon the human beings that the Sisters also generated in those places. ${ }^{17}$ Along their journeying their acts were the same but their languages changed and thus the names they bestowed to places were different. Places are named as they are shaped, names are placed as they shape the landscape. Just as the Sisters imprinted the ground by making a freshwater spring flow, they also named the country where the spring is now located. Also, the walking stick planted in the ground metamorphosed itself into a tree which was given an 'elbow name'. Wherever they shaped the ground by imprinting it (nhirrpan) or by planting the stick which metamorphosed into a tree, the Sisters named the place. Places are shaped by 'piercing' (nhirrpan) the ground, and by bringing the water there (dha:rra) and by making the walking stick 'stand' (dha:rra) as a tree. The piercing of the ground contains a sexual component. In piercing the ground the actions of the two Sisters gave rise to humans who, like the trees and water springs, are thus given shape and 'stand' (dha:rra) to populate places.

Perhaps it is not a coincidence that proper names are 'pierced' or given (nhirrpan) and are said 'to stand' or belong (dha:rra) to people and to places. 'This is a person's name' is the translation of Yolnguwal dhuwal ya:ku ga dha:rra (literally, 'at a person this name stands') and 'I gave her this name' is rendered with dhuwal nhanukal ngarra nirrpanha (literally 'this name to her I pierced or planted'). Given that names are 'planted' or 'pierced' (nhirrpan) and

did not steal them, they got up onto the Sisters' skin and took them with their bodies. They did not steal them but the Sisters did not give them.'

15 Male proper name held by a Djambarrpuyngu man, sister's daughter's son (ZDS) of the Liyagalawumirr clan, owner of the Djang'kawu song cycle.

:6 The clan songs recounting the Sisters' journeys are different in musical form from other clan songs of the same moiety as they are not performed with a drone pipe but only to the accompaniment of the sound of the clapping sticks. The result is an almost hypnotic music which echoes the regular pacing rhythm of walking. Similar to the unique 'walking' quality of the music, dancers shuffle their feet not in the characteristic 'skipping' style but in a slow forward and backward dragging movement.

17 The same images of planting digging sticks which then metamorphose into trees are also to be found in the Yirritja moiety morphogenetic stories. Wherever any Ancestral Beings speared the ground in Yirritja countries, an ironwood tree (maypiny, generic) now stands. 
'stand' (dha:rra) at places or with people, it might even be suggested that, as the shaping of the ground involves the act of naming and, conversely, names imply and embody actions of imprinting and metamorphosis, a person, an object or a phenomenon is not the bearer of a name, but its embodiment.

It is here pertinent to note that Yolngu language reflects this 'indissoluble connection' between name and person in what linguists have referred to as 'the grammar of inalienability', namely 'a permanent and inherent association between the possessor and the possessed' (Chappell \& McGregor 1996:4). In relation to proper names it should thus be noted that the personal pronoun rather than the possessive is used; thus 'my name is Franca' is rendered as 'I name Franca' (ngarra ya:ku Franca). As Stanner (1937:301) insightfully points out, the name does not only relate to one's personality 'as the shadow or image does to the sentient body', but 'is like an intimate part of the body, with which another person does not take liberties' (Stanner 1979a:25).

The intrinsic connection between naming and the ancestral processes of morphogenesis through movement and action is further elaborated and will be more clearly explained by the meaning and practice of guykthun, a term I gloss with 'spurting' or 'vomiting'. This notion, to which I now turn, requires special attention as it elucidates the link between naming, names and the transformative bodily process of externalisation.

\section{THE ACT OF GUYKTHUN}

The term guykthun is a recurrent action through which several Ancestral Beings of both moieties are said to have given shape to the clouds. ${ }^{18}$ The following is a simplified and abbreviated extract from a tape transcription of Lalangbuy's explanation of the story of how the Rainbow Serpent shaped particular clouds by the action of 'the spurting of words' (guykthun).

I am going to sing to you what you can see there and what a Yolngu told us when we took over that snake, a water python in that inlet called $\left({ }^{*}\right)$. There at $\left(^{*}\right)$, the snake 'spurted words' (guykthun) and (then) went back home. It is here that your snake is asleep. This snake is a water python, a $\left.{ }^{*}\right)$ snake. There, maybe, in his shelter he spilled sacred words towards the sea water and there stood (dha:rra) low white clouds (coming) from his spurting (guykthun). Just those clouds you might have seen in the paintings, they stand over there, they are called $\left(^{*}\right)$ and $(*)$. They are formed (mali'bakthuna) from him, there, just from that spurting of the snake. And then the snake goes back, over there, to his home, he returns, he proceeds swaying his tail. (Lalangbuy: extract of conversation recorded by the author in Milingimbi, field tapes 1991)

18 The expression guykthun has several meanings in different contexts. While these are important to understand the complexity of this notion, they can only be mentioned very briefly here. 1) guykthun can be glossed as 'cursing' in that the 'spilling' of words makes someone or something sacred or tabooed until the curse is lifted once an agreement is reached by the parties involved; 2) in preparation for circumcision the boy's own group's design is painted on his chest and water mixed with clay is sprayed on his face (buku guykthun literally 'face spraying'); with this act the boy becomes the recognised owner of the manifestation of the Ancestral Being(s) painted on his chest; 3) Buku guykthun is a synonym of wama:rrkanhe, an expression which is usually but not only pronounced in complimenting a singer or dancer's virtuosity in performance. In this case guykthun may be glossed as 'face which has been sprayed with appreciation' (see Tamisari 2000 for a detailed account of what I refer to as the 'curse of compliments'). In everyday language, the term gakthun means 'to vomit'. 
It is by spurting sea water (implied in the word guykthun) and by the 'spilling of words' (also guykthun) that the Serpent gave shape to the clouds. ${ }^{19}$ It is in fact by a combination of the regurgitation of water and the 'spilling of names' that the clouds are said to have been given their shape and names. In Lalangbuy's explanation quoted above, I translated mali'bakthuna as 'formed'. It is, however, important to specify that the verb is composed of the word mali' meaning 'shadow', 'image' or 'semblance' and bakthun which may be translated as 'to break off', 'finish off'. I suggest that this term stresses the creation process of making, shaping the likeness of clouds through a process of 'breaking off' from or externalising a body part of the ancestor. ${ }^{20}$ This act is not only performed by naming but comes about also by the embodiment of the Serpent's morphogenetic actions through externalisation. The clouds thus shaped can be said to be a manifestation of the Serpent through words and actions. These clouds are sacred and, in paintings, they are usually represented together with the Serpent in the form of triangles. It follows that the names of these clouds embody this manifestation and with it the morphogenetic power of the Ancestral Being. The name that constitutes these clouds through this particular action is thus considered a 'big name' (yindi ya:ku). The 'spurting of water' is not only a metaphor for uttering words but the means by which the manifestation of the Serpent's body through spurting is externalised and becomes forms.

What I would like to stress here is that the act of naming is made powerful and performative through externalisation and suggests a complex series of transformations in which body, language and place constitute each other. The ancestral externalisation of power in action and movement, therefore, gives words their morphogenetic power which is expressed in the term guykthun. Similarly, the term is also used in other contexts in which words acquire specific potency and have particular effects. In the several contexts in which the term guykthun is used, for instance as in cursing (see fn 18), the words pronounced by particular actors are not only performative as defined by Austin (1962), but they are better described as a poiesis, a disclosing, a bringing into presence. ${ }^{21}$

\section{THE KINETIC QUALITIES OF NAMES}

Having considered how the act of naming and ancestral bodily actions give shape to places, I would like to briefly consider the ways in which names condense these actions in describing their topographic and kinetic characteristics. For this purpose I will refer to four names of a place at which ancestral fresh water first appeared to begin its journey across the country of a Yirritja group. The names of the place where the water bubbled up from inside the ground refer to specific aspects of this event, they are:

19 Other Ancestral Beings of both moieties are said to have created natural phenomena such as clouds, and/or places through 'the spurting of water and words'. One such example is a Sea Snake of a Dhuwa group.

20 See Morton's (1987:108) discussion of a similar Arrernte term. Another Yolngu term, $\left({ }^{*}\right)$, refers to the action of 'biting' (literally 'lock in mouth') as well as to naming. Another expression is (*), literally, 'swim-bladder-speak'. By throwing a part of its body onto the beach a fish ancestor of one clan of the Yirritja moiety named and shaped landscape features such as trees in the form of the organ that had been externalised. The terms for these actions are omitted as they are now part of names of places thus shaped.

21 Austin defines performatives as 'doing something as opposed to just saying something' (1962:133), however stressing that 'it is not to perform an act in some specially physical way, other than in so far as it involves, when verbal, the making of movement of vocal organs' (1962:134). 
1) (*): this name renders as 'to swell up to shake and tremble' and refers not only to the force and impetus with which the ancestral water came up but also to the effect produced on the surface of the ground;

2) (*): evokes the sound produced by the water rushing to the surface of the opening;

3) (*): this name can be translated as 'fresh water pandanus-LOC' and provides an image of the surrounding landscape where the ancestral action took place;

4) $(*)$ : this name refers to an ancestral fish which, with the water, emerged from the opening in the ground.

These four names evoke rather than describe particular details of an action. Name number one evokes the kinetic energy of the water pressing from underneath the ground; number two is an onomatopoeic name which suggestively reproduces the sound of gushing water; name number three describes the adjacent environment to the action; and name number four stresses the direction of the action from inside to outside and introduces another Ancestral Being which, transported by the water, will cross the length of this group's country shaping and naming the country. Here I would like to focus on name number four, a name that evokes movement rather than sound. It is in reference to this aspect that I speak of 'kinesiopoeic' names and nouns: a neologism I propose for those names and nouns that evoke the movement associated with the thing or action designated. In the context of ancestral travelling over long distances, these kinesiopoeic names highlight the significance of movement that connects places along the route of a particular journey. The sites at which Ancestral Beings have emerged and/or stopped to shape the land are connected by paths marked by the ancestral body in movement. I suggest that these kinesiopoeic nouns (which may also be names of people and places) convey the incessant movement of what may be referred to as the "sitepath flow' (Munn 1973:137) of ancestral journeying. These nouns capture and reproduce either a linear motion that traces a path between places or evokes a localised bodily movement at a particular place. Yolngu song texts are replete with these nouns. Here it is important to note that these nouns are often but not always associated with and performed as dance movements.

Some examples of names and nouns that evoke linear and localised movement are listed below:

\section{linear movement}

$(*)$ : also a proper male name, this noun evokes the water displaced by a fish ancestor at a particular site. As the fish advances towards the land, the water surrounding him forms a wave which precedes him to the shore. This noun is repeatedly sung while a line of dancers advances frontally interlocking their spears at thigh-height.

(*): evokes the swimming motion of the turtle in the water. This noun is repeated in the song text and refers to both the linear trajectory of the turtle through the water as well as the wake or track she leaves behind in the water and on the land at specific places. The turtle's characteristic movement is also imprinted on the ground by the advancing steps of the performer of this dance (see Tamisari 2000). 


\section{localised movement}

(*): this noun refers to the strength and might of the sea waves at a particular place in a storm following the heavy monsoon rains. More precisely this term compares the upright, curved shape of the wave to the sudden and violent movement that arches the body in the act of retching.

(*): also a female proper name, this noun evokes the bobbing movement of driftwood floating on the little waves of the calm sea water after a storm at particular places. Dawu pudat, one of the several expressions frequently repeated in the driftwood song units, combines sound with movement in a suggestive way. Dawu refers to the sound of water slapping the floating driftwood, while pudat evokes its 'floating dance along the calm water' as the song text says. In the corresponding dance, performers hold a stick at either extremity and lift it up and down parallel to the ground.

\section{CONCLUSION}

I have considered elsewhere the image of the footprint and especially its ontological significance in relation to the accumulation and transferral of knowledge and its negotiation in the context of individual and group identity (Tamisari 1998). As with landscape features, Yolngu people talk of stories, kinship, songs, painting and dances as 'footprints' (djalkiri) of the ancestors. Djalkiri or luku (literally 'foot' and by extension 'footprint' and 'step') is the term often used to refer to different aspects of Yolngu Law (rom) which originated from ancestral journeys and actions that shaped the land. Djalkiri, the footprint, thus refers to all visible marks left by the Ancestral Beings such as landscape features (wa:nga), kinship relationships among groups derived from their positioning along an ancestral trajectory (gurrutu), to the stories that recount the Ancestral Beings' journeys and actions (dha:wu, CF. Marika-Mununguritj 1991). These visible marks or 'footprints' are continuously manifested and retraced in paintings (dhulang), songs (manikay) and dances (bunggul). In this context I argue that the image of the footprint has ontological significance in that it is not simply the result, objectification or inscription of ancestral and human experiences and events in and on the land. In phenomenological terms the 'footprint', I assert, is a 'living body' and a 'knowing body', an embodied consciousness and perception of and in the world, simultaneously a fragment and an agent of place, a product and actor of social relations, a subject and object of action and experience. Djalkiri, the 'footprints' of the ancestors, the manifestation of ancestral creativity, not only fuse the body, place and event in an indissoluble whole, but mark connections between places, establish relationships between people, visualise movement, unravel narratives, and embody names. In this paper, I have further shown how this fusion of body, place and event is condensed in names, and conversely names are manifestations of ancestral morphogenetic actions. As 'footprints' not only placenames but proper names in general reveal once again the corporeal connection between people, places and ancestors. As a 'footprint' is static but implies movement, is localised but can be considered only in relation to other footprints which together form a journey, names localise and at the same time connect. While names embody an event into place and identify a place with a particular group or individuals, they often imply that these connections are temporary stops along an evermoving trajectory which distributes unique ownership of country within a shared knowledge and authority over wider regions. 
From this perspective, I suggest that Yolngu names may thus be considered, as Heidegger argues, as 'signs of things' (1971b:97), however not in its 'debased meaning - lines on a surface' (1971b:121). The naming of the landscape which brings a localised feature or phenomenon into existence through the processes of metamorphosis, imprinting and externalisation, as originating from the ancestral body, should be approached 'de-signs' in which the word sign should be understood in its etymological meaning of cutting a trace from the Latin secare as in saw, sector, segment and section. A de-sign says, shows, discloses, lets appear and determines things as things in the world (1971b:121ff). If names say the world into existence rather than representing it, bring it to presence rather than communicating it, it is this saying that lets one see and understand. Like poetry, which Heidegger describes as revealing and fixing the play between words and things, language and being, Yolngu names participate in the process of emplacing things into presence which, through bodily transformations, become an integral part of the world. I suggest that the significance and power of names thus reside in their corpo-reality or bodiliness: indeed their ability of 'designing' and thus showing and making appear, or in Yolngu terms 'piercing' and 'spurting' a visible mark which fixes acting Bodies, their history and experiences into the landscape features and localises phenomena that constitute places. ${ }^{22}$ Thus by combining the act of naming with bodily transformations and fusing names with things as indissoluble manifestations of ancestral morphogenesis, Yolngu cosmogonic processes may be more appropriately referred to as a morphopoiesis, that is speaking forms into place, the making of place through names.

\section{ACKNOWLEDGMENTS}

I wish to thank all Yolngu people of Milingimbi community and especially my adoptive family for teaching me. Although I omitted proper names and avoided other details, I hope my discussion has respected their trust and the cultural sensitivities they are required to live under or observe.

\footnotetext{
22 The corporeal interpenetration of places, people and ancestral events which is exemplified in the processes of 'piercing' and 'spurting' the world into being is not limited to names. The act of painting is referred to as miny'tji yarpuma, literally, 'paint/colour jabbing or spearing' (cf. Morphy 1989:24). The significance of this terminology has been recently noted in the sand designs made by women in the Balgo area (Watson 1997:110).
} 


\section{REFERENCES}

Austin, John L., 1962, How to Do Things with Words. Oxford: Oxford University Press.

Basso, Keith H., 1988, 'Speaking with names': language and landscape among the Western Apache. Cultural Anthropology 3(2):99-130.

- 1996, Wisdom sits in places: Notes on a Western Apache landscape. In Steven Feld and Keith Basso, eds, Senses of Place, 53-90. Santa Fe: School of American Research Press.

Berndt, Ronald, M., 1952, Djanggawul: an Aboriginal religious cult of north-eastern Arnhem Land. London: Routledge \& Kegan Paul.

Biddle, Jennifer, 2000, Writing without ink: methodology, literacy and cultural difference. In Alison Lee and Cate Poynton, eds, Culture and Text: discourse and methodology in social research and cultural studies, 170-187. St Leonards, NSW: Allen \& Unwin.

Casey, Edward, S., 1996, How to get from space to place in a fairly short stretch of time: phenomenological prolegomena. In Steven Feld and Keith Basso, eds, Senses of Place, 13-52. Santa Fe: School of American Research Press.

Chappell, Hilary and William McGregor, 1996, The Grammar of Inalienability: a typological perspective on body part terms and the part-whole relation. Berlin: Mouton de Gruyter.

Dussart, Francoise, 1988, Notes on Warlpiri women's personal names. Journal de la Société des Oceanistes 96(1):53-60.

Goodale, Jane, 1980, Tiwi Wives: A study of the women of Melville Island, North Australia. Seattle: American Ethnological Society; University of Washington Press.

Hart, C.W.M., 1930, Personal names among the Tiwi. Oceania 1(3):280-290.

Heidegger, Martin, 1971a, Poetry, Language, Thought. Trans. Albert Hofstander. New York: Harper \& Row.

- 1971b, On the Way to Language. Trans. Peter D. Hertz. New York: Harper \& Row.

Keen, Ian, 1978, One ceremony one song: an economy of religious knowledge among the Yolngu of north-east Arnhem Land. PhD dissertation, Canberra: The Australian National University.

- 1991, Images of reproduction in the Yolngu Madayin ceremony. The Australian Journal of Anthropology, Special Issue 1:192-207.

- 1994, Knowledge and Secrecy in an Aboriginal Religion. Oxford: Clarendon Press.

— 1995, Metaphor and the meta-language: 'groups' in Northeast Arnhem Land. American Ethnologist 22(3):502-527.

Lévi-Strauss, Claude, 1966, The Savage Mind. London: Weidenfeld and Nicolson.

McKnight, David, 1999, People, Countries, and the Rainbow Serpent: systems of classification among the Lardil of Mornington Island. New York: Oxford University Press.

Marika-Mununguritj, R. 1991. How Can Balanda (White Australians) Learn About the Aboriginal World. Batchelor Journal of Aboriginal Education July:17-23. 
Morphy, Howard, 1989, From dull to brilliant: the aesthetics of spiritual power among the Yolngu. Man 24(1):21-40.

- 1990, Myth, totemism and the creation of clans. Oceania 60(4):312-328.

- 1995, Landscape and the reproduction of the ancestral past. In Eric Hirsch and Michael O'Hanlon, eds, The Anthropology of Landscape: perspectives on place and space, 184 209. Oxford: Clarendon Press.

Morton, John A., 1987, Singing subjects and sacred objects: more on Munn's transformation of subjects into objects in Central Australian myth. Oceania 58(2):100-118.

Mundine, Djon, 2000, The Native Born: objects and representations from Ramingining, Arnhem Land. Sydney: Museum of Contemporary Art in association with Bula'bula Arts, Ramingining.

Munn, Nancy, 1970, The transformation of subjects into objects in Walbiri and Pitjantjantjara myth. In Ronald M. Berndt, ed., Australian Aboriginal Anthropology, 178-207. Perth: University of Western Australia Press.

- 1973, Walbiri Iconography: graphic representation and cultural symbolism in a Central Australian society. Ithaca and London: Cornell University Press.

- 1996, Excluded spaces: the figure in the Australian Aboriginal landscape. Critical Inquiry 22(Spring):446-465.

Nash, David and Jane Simpson, 1981, 'No-name' in Central Australia. In Carrie S. Masek, Roberta A. Hendrick and Mary F. Miller May, eds, Papers from the Parasession of Language and Behavior, 1-2:165-177. Chicago: Chicago Linguistic Society.

Schebeck, Bernard, 1968, Dialect and social groupings in North East Arnhem Land. Unpublished manuscript. Canberra: Australian Institute of Aboriginal and Torres Strait Islander Studies.

Stanner, William E.H., 1937, Aboriginal modes of address and reference in the north-west of the Northern Territory. Oceania 3(7):300-315.

- 1979a, The dreaming. In William E.H. Stanner, White Man Got No Dreaming. Essays 1938-1973, 23-40. Canberra: Australian National University Press (first published in 1953).

- 1979b, Religion, totemism and symbolism. In William E.H. Stanner, White Man Got No Dreaming. Essays 1938-1973, 106-143. Canberra: Australian National University Press (first published in 1962).

Strehlow, Theodore G.H., 1947, Aranda Traditions. Melbourne: Melbourne University Press.

Tamisari, Franca, 1998, Body, vision and movement: In the footprints of the ancestors. Oceania 68(4):249-270.

-2000 , The meaning of the steps is in between: dancing and the curse of compliments. In Rosita Henry, Fiona Magowan and David Murray, eds, The Politics of Dance. Special Edition 12, The Australian Journal of Anthropology 11(3):274-286.

Thomson, Donald, 1946, Names and naming in the Wik Monkan tribe. Journal of the Royal Anthropological Institute 76(2):157-167. 
von Sturmer, John, 1978, The Wik region: economy, territoriality and totemism in western Cape York Peninsula, North Queensland. PhD dissertation, University of Queensland.

Warner, Loyd, 1958, A Black Civilisation: a social study of an Australian tribe. New York: Harpers and Brothers.

Watson, Christine, 1997, Re-embodying sand drawings and re-evaluing the status of the camp: the practice of iconography of women's public sand drawings in Balgo, Western Australia. The Australian Journal of Anthropology 8(1):104-124.

Williams, Nancy, 1986, The Yolngu and Their Land: a system of land tenure and the fight for its recognition. Canberra: Australian Institute of Aboriginal Studies. 